\title{
Selective Disintegration Justification Based on the Mineralogical and Technological Features of the Polymetallic Ores
}

\author{
Tatiana Aleksandrova (D), Nadezhda Nikolaeva *, Anastasia Afanasova (D), Artyem Romashev (D) \\ and Valentin Kuznetsov
}

Citation: Aleksandrova, T.;

Nikolaeva, N.; Afanasova, A.;

Romashev, A.; Kuznetsov, V. Selective Disintegration Justification Based on the Mineralogical and Technological Features of the Polymetallic Ores. Minerals 2021, 11, 851. https:// doi.org/10.3390/min11080851

Academic Editor: Bernhard Schulz

Received: 25 June 2021

Accepted: 4 August 2021

Published: 7 August 2021

Publisher's Note: MDPI stays neutral with regard to jurisdictional claims in published maps and institutional affiliations.

Department of Mineral Processing, Saint Petersburg Mining University, 199106 St. Petersburg, Russia; alexandrovat10@gmail.com (T.A.); afanasovaop-10@yandex.ru (A.A.); romashev_ao@pers.spmi.ru (A.R.); valentinvadimovichkuznetsov@gmail.com (V.K.)

* Correspondence: nadegdaspb@mail.ru

\begin{abstract}
Deterioration of mineralogical and physical characteristics of mineral raw materials results in the formation of the primary task for the comminution processes-reduction in the size of ore to obtain a material with a certain granulometric composition, which in turn is achieved by overgrinding of raw materials and, consequently, an increase in energy costs. The work aimed to justify the possibility of selective disintegration of mineral assemblages of polymetallic ores of various genesis at the stage of crushing based on in-depth investigation and revealing of interrelation and mutual influence of mineralogical-geochemical features, textural-structural and technological properties. Structural and textural features have been studied by the methods of computed X-ray microtomography. Experimental and theoretical investigations of mineralogical and technological parameters of raw materials, as well as research on crushing using different types of crushers, made it possible to substantiate the possibility of selective disintegration for polymetallic ores.
\end{abstract}

Keywords: selective disintegration; thixomet; mineral assemblages; mineral liberation; X-ray computed tomog pore space structure; hardness

\section{Introduction}

In view of reserves exhaustion for easy to enrich raw materials and in order to compensate for the growing shortage of high-grade ores, it becomes imperative to involve unconventional types of ore deposits in exploitation [1-5]. However, the exploitation of such deposits entails an increase in costs of extraction and mineral processing. Process engineers are constantly trying to find options for the rational organization of ore dressing processes within the framework of existing and emerging ore dressing technologies, which allow for a reduction in losses in the dressing processes due to a more complete disclosure of grain aggregates [6-8].

Crushing and grinding processes, in which the destruction occurs under the action of external forces, are used for mineral raw materials destruction and aggregate disclosure. These processes are based on the creation of strain stress fields in the destructible object that will exceed the ultimate strength characteristics of the material. Their main goal is to break the bonds of the crystal lattice with the formation of a new surface.

The destruction itself occurs mainly in the weakened profiles with defects, after the normal and tangential stresses arising in the material during its elastic deformationsimpact, crushing, splitting, abrasion, fracture [8-12]. Practical comminution processes that are used to reduce the size of minerals are, for the most part, non-selective. The resulting particles consist of a mixture of mineral components present in the original ore. However, there is a natural tendency to release particles that are smaller than the mineral grains found in the ore during the disintegration. This is primarily caused by the constant 
deterioration of a mineral raw material's mineralogical and geochemical characteristics. Analysis of the scientific and technical literature has shown that crushing and grinding operations are generally regarded as non-selective, i.e., cracks in the rock do not correlate with the basic mineralogical texture of the ore. Crushing and grinding operations can be considered conceptually as an overlay of an extensive fracture network through the complex heterogeneous mineralogical texture of the ore. The fracture network ultimately determines the degree of liberation and particle size distribution of the milling products. The relationship between the crack network and mineralogical texture determines how mineral phases are distributed among the particles in the volume after fracture $[13,14]$. With gradual grinding, the particle size decreases, and the fraction of fractured particles increases. As the value of product concentration and particle size decreases, the energy requirement for grinding gradually increases [15-17].

The development principle for technologies of mineral assemblages selective disintegration based on the investigation of a raw material's mineralogical, geochemical and technological features is a promising direction for processes of disintegration development $[15,18]$. The basis of the selective disintegration of mineral assemblages is the emergence at the interface of the mineral's concentration of stresses, exceeding the strength of their bonding [19]. Thus, an important aspect of the investigation of selective disintegration of mineral assemblages is the research of the bond nature between minerals. That involves the investigation of issues such as:

- research of the boundary morphology for structural elements [20];

- $\quad$ size-mineral distribution (according to thin sections and thinned polished sections) [21-23];

- the specific surface of the inter-and intraphase boundaries [24,25];

- $\quad$ the share of matrix structures [26,27];

- fracturing [28].

The practice of crushing and grinding of mineral raw materials allows us to distinguish several types of selective destruction depending on the material nature and destruction product's purpose and directions of using [13]:

- $\quad$ selective destruction of materials by separative characteristics (e.g., selective opening of ore minerals from host rocks);

- $\quad$ selective destruction by shape (obtaining products of a given geometric shape);

- $\quad$ size-selective destruction (to obtain the maximum yield of the product of a given size).

The investigation of raw material mineralogical features allows the possibility of selective disintegration implementation to be determined. For example, raw materials with idioblastic character of mineral intergrowth are predisposed to selective disintegration, while myrmekite intergrowth of mineral assemblages stipulates the impossibility of selective disintegration [20,29].

Another aspect of the selective disintegration of mineral assemblages is particularly difficult - the selection of equipment for the disintegration. In primary and secondary stages, crushing product which is much larger than the size of the exposed grains is obtained. In turn, tertiary crushing is the stage of product formation, which is a structural element of liberation. Therefore, of particular interest is the study of this very stage of ore disintegration, immediately before the grinding cycle. Moreover, in this case, classification and screening operations in crushing schemes can be used as stages of effective preconcentration [21,30]. In [5], a characterization of crushing and grinding devices, depending on the factors of destruction, is presented. According to the classification presented, jaw, cone, and roll crushers are hard-loaded crushers, while impact, centrifugal and inertial crushers are soft-loaded equipment. The main distinction of soft-loading equipment is that during the crushing process, all the energy transferred to the ore lump by the loading device is completely converted into deformation energy. The kinetic energy of lumps of rock is converted into the potential energy of elastic deformation, which is then transformed into other types: fracture energy, heat, the kinetic energy of flying particles, and surface energy. This further leads either to overgrinding of the material or to the accumulation of 
hidden cracks. The second case creates prerequisites for further selective disintegration of mineral assemblages [19,31,32].

The mineral resources sector is a very important element of the world economy. In this regard, the improvement of existing technologies for mineral raw materials processing is an imperative task [33-35]. An important area of research is the technology development for selective disintegration of mineral assemblages, based on an in-depth investigation of a material's mineralogical, geotechnical, and technological characteristics. Another area is conducting direct experimental studies using equipment with different types of loading due to the complexity of assessing the destruction factors of the used crushing and milling equipment [36]. Thus, the purpose of this work was to study the mineralogical and technological features of polymetallic ores of two genetic types to justify the possibility of selective disintegration.

\section{Materials and Methods}

$\mathrm{Au}$-bearing ores from Bamskoye (BDO) and $\mathrm{Cu}$-Ni ores from Oktyabrskoye (CNO) deposits were used for this research. The location map of these deposits is shown in Figure 1.

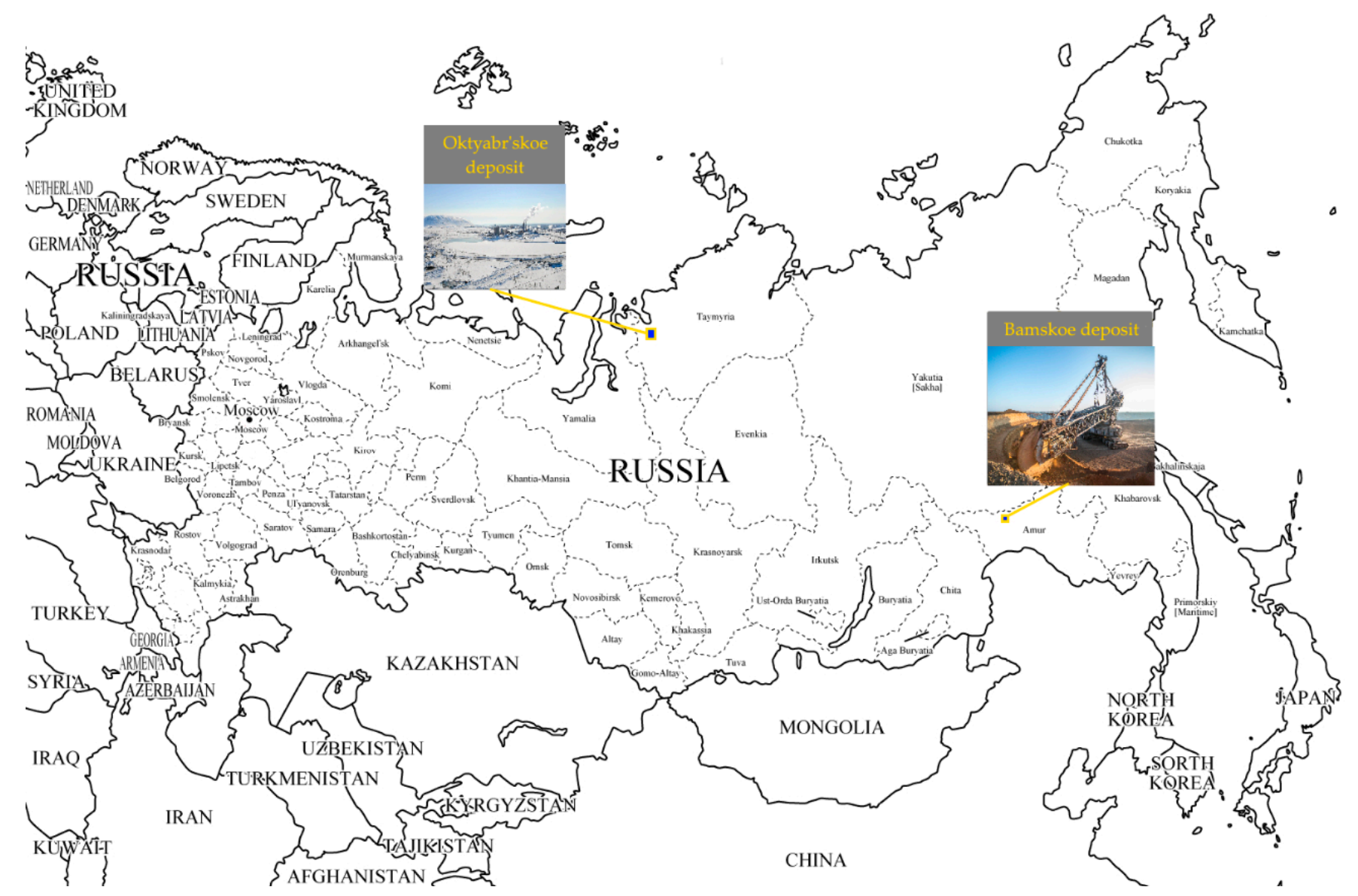

Figure 1. Location of the Bamskoe deposit and the Oktyabrskoye deposit.

The samples were selected according to the following criteria: both samples are polymetallic ores. The ores of the Bamskoye deposit (Figure 2) are fine- and mediumgrained from mainly vein disseminated ores.The copper-nickel ore of the Oktyabrskoye deposit (Figure 3), is coarse-grained from continuous veins, which is likely to have a significant effect on comminution performance and processing potential. 

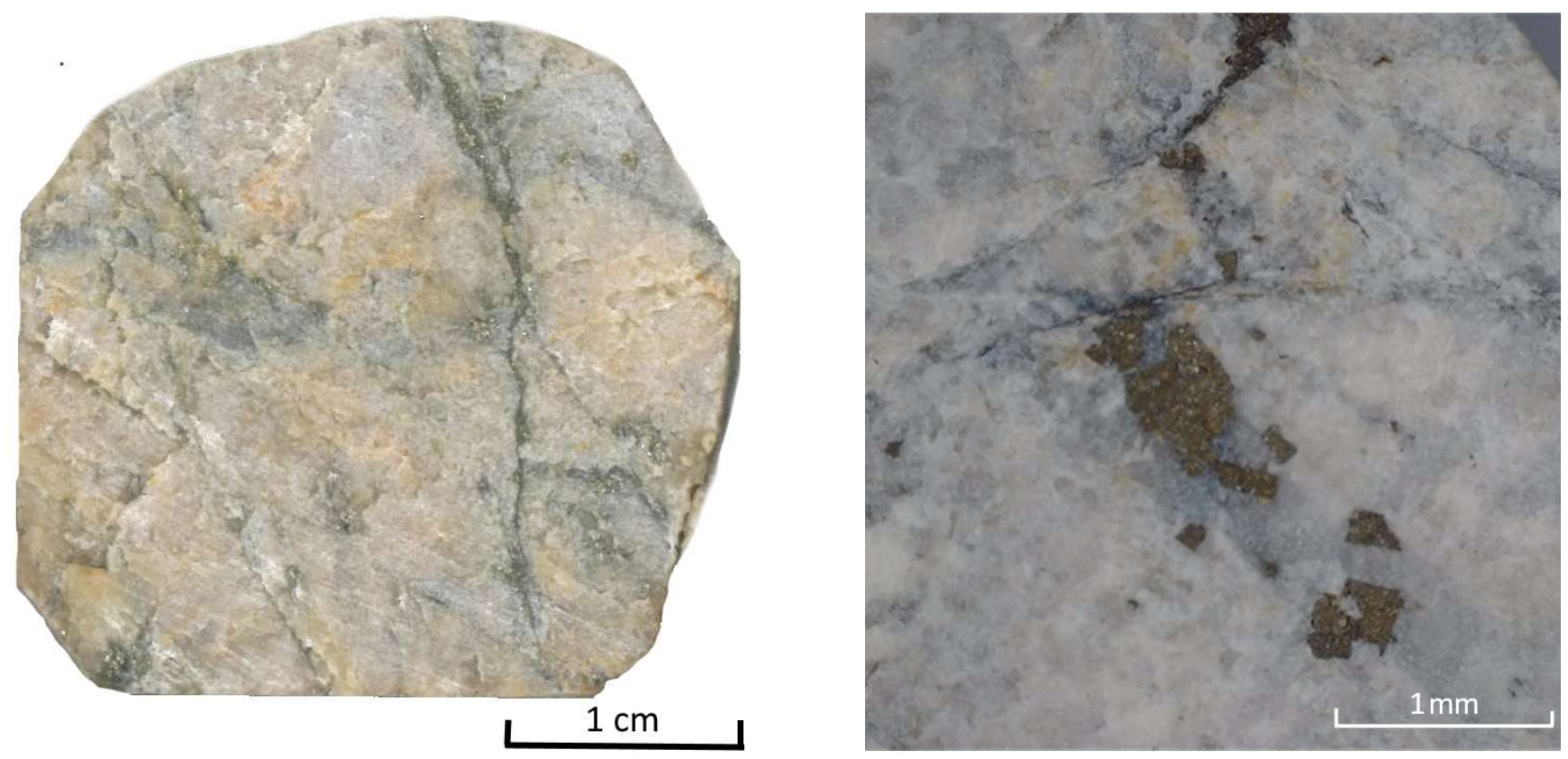

Figure 2. Bamskoe deposit's ore samples.
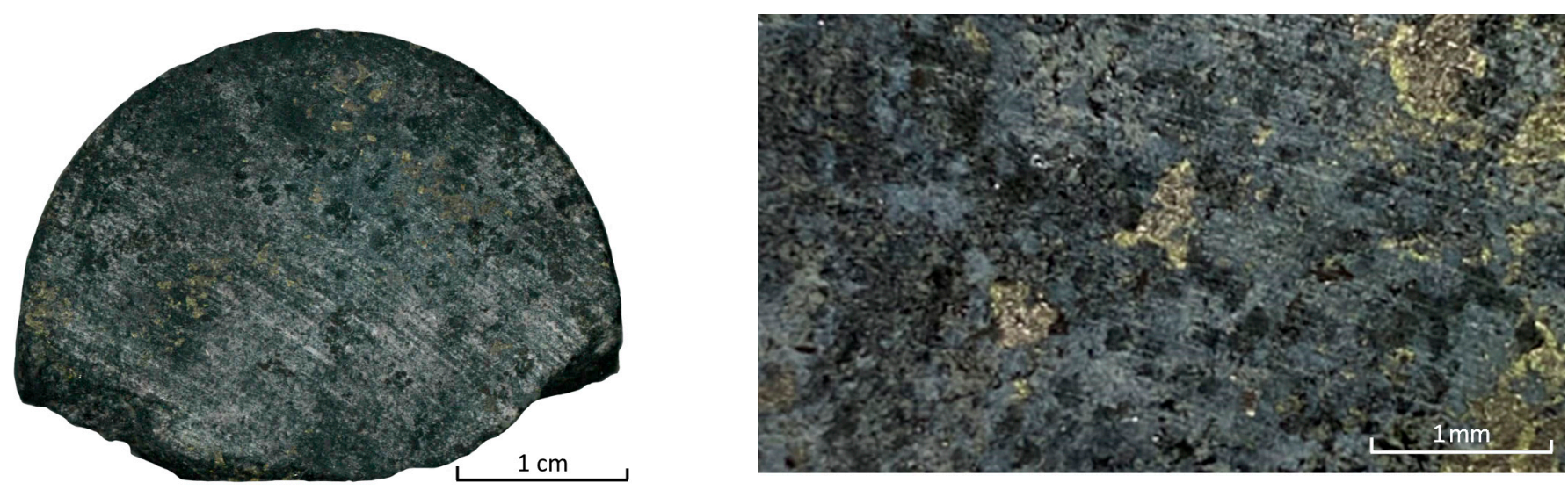

Figure 3. Copper-nickel ore of the Oktyabrskoye deposit.

The Bamskoe deposit comprises gold-quartz low quantity sulfide ores [37]. It is a large gold ore object with relatively high grades of gold. Valuable components in the ore are represented by gold and silver by-products-copper and tungsten. The ore contains rock-forming minerals (such as quartz, feldspars, mica, sericite, carbonates, etc.) and ore minerals (native gold, chalcopyrite, pyrite, scheelite, silver, etc.). The gold content in samples varies from $0.01 \mathrm{ppm}$ to $150 \mathrm{ppm}$ (average content-5.9 ppm) and the silver content may contain up to 200 ppm (average content-16.9 ppm). Au:Ag ratio = 1:3.

The main valuable components in Norilsk copper-nickel ores (including coppernickel ore of the Oktyabrskoye deposit) are copper and nickel with the grade's value range from $0.661 \%$ to $1.334 \%$ and $0.408 \%$ to $1.064 \%$, respectively [38]. The titanium content varies from $0.96 \%$ to $1.44 \%$. The titanium concentrator mineral is ilmenite, according to the mineralogical analysis. The silicon and calcium content in the samples varies from $15.81 \%$ to $18.86 \%$ and from $7.94 \%$ to $9.06 \%$, respectively, with rock-forming minerals such as olivine, pyroxene, and plagioclase.

In order to determine the chemical composition of studied samples, the Energy Dispersive X-ray Fluorescence analysis method was used (Tables 1 and 2). 
Table 1. Results of the study of the chemical composition of BDO.

\begin{tabular}{cccccc}
\hline Element & Content, $\%$ & Element & Content, $\%$ & Element & Content, \% \\
\hline $\mathrm{Si}$ & $26.39 \pm 1.32$ & $\mathrm{Ca}$ & $24.57 \pm 1.23$ & $\mathrm{Ag}$ & $0.0726 \pm 0.0036$ \\
$\mathrm{~S}$ & $3.98 \pm 0.20$ & $\mathrm{Zn}$ & $0.67 \pm 0.03$ & $\mathrm{Au}$ & $0.0225 \pm 0.0011$ \\
$\mathrm{Fe}$ & $12.36 \pm 0.62$ & $\mathrm{Ti}$ & $0.088 \pm 0.004$ & $\mathrm{Al}$ & $3.29 \pm 0.16$ \\
$\mathrm{~K}$ & $22.19 \pm 1.11$ & $\mathrm{Mn}$ & $2.35 \pm 0.12$ & $\mathrm{Ni}$ & $0.050 \pm 0.002$ \\
\hline
\end{tabular}

Table 2. Results of the investigation of the chemical composition of CNO.

\begin{tabular}{cccccc}
\hline Element & Content, $\%$ & Element & Content, \% & Element & Content, \% \\
\hline $\mathrm{Si}$ & $25.24 \pm 1.26$ & $\mathrm{Ti}$ & $1.68 \pm 0.08$ & $\mathrm{Cr}$ & $0.352 \pm 0.018$ \\
$\mathrm{Fe}$ & $34.72 \pm 1.74$ & $\mathrm{~K}$ & $1.91 \pm 0.10$ & $\mathrm{~V}$ & $0.070 \pm 0.004$ \\
$\mathrm{Ca}$ & $12.47 \pm 0.62$ & $\mathrm{Cu}$ & $1.333 \pm 0.067$ & $\mathrm{Sr}$ & $0.088 \pm 0.004$ \\
$\mathrm{Al}$ & $5.07 \pm 0.25$ & $\mathrm{Ni}$ & $0.940 \pm 0.047$ & $\mathrm{Zn}$ & $0.092 \pm 0.005$ \\
$\mathrm{~S}$ & $2.64 \pm 0.13$ & $\mathrm{Mn}$ & $0.42 \pm 0.02$ & $\mathrm{Zr}$ & $0.043 \pm 0.002$ \\
\hline
\end{tabular}

Thin sections and thinned polished sections were prepared for investigation of their mineralogical features. The thin sections and thinned polished sections were examined using a Leica DM2700P (Leica Microsystems GmbH, Wetzlar, Germany) polarization microscope for working in transmitted and reflected light, complete with a Leica DFC495 digital camera (Leica Microsystems $\mathrm{GmbH}$, Wetzlar, Germany). The shape of mineral aggregates was analyzed using an Axio Imager A2m (Zeiss, Jena, Germany) optical polarization microscope coupled with the Thixomet PRO software (Thixomet PRO, Thixomet, St. Petersburg, Russia) package. The obtained images were analyzed in the Thixomet PRO software package to determine metric parameters of the grains, such as area, perimeter, elongation, and edge roughness, which enable the quantitative assessment of mineral grains in the examined samples. The area and perimeter $(P)$ of the object are calculated by the program automatically, with result data obtained on the length $(L)$ and width $(B)$ of grains. Additionally, the program determines the perimeter of the convex hull $(P c)$ of the object and the convex area found from the convex perimeter. The coefficient of grain elongation is calculated by the ratio of the grain length to its width $(L / B)$. The coefficient of edge roughness, in this case, is defined as the ratio of the perimeter of the grain to the convex perimeter of the grain $(P / P s)[39]$.

Analysis of the material and chemical composition was performed using atomic absorption, X-ray fluorescence method (Shimadzu EDX-7000, Shimadzu Corporation, Kyoto, Japan). Morphometric parameters were studied by computed tomography (microtomograph "SkyScan-1173", Brucker, Kontich, Belgium). Exposure parameters for sample microtomography are given in Table 3.

Table 3. Exposure parameter set of computed X-ray microtomography.

\begin{tabular}{cc}
\hline Parameters & Value \\
\hline Accelerating voltage, $\mathrm{kV}$ & 125 \\
Current strength, mA & 61 \\
Resolution, mic & 32.32 \\
Filter, mm & Brass 0.25 \\
Rotation step, degrees & 0.100 \\
\hline
\end{tabular}

Experimental studies were carried out on the facilities of the St. Petersburg Mining University (jaw crusher, roll crusher, impact crusher, ball mill, JK drop weight tester, Bond impact test, Bond ball and rod mills, laser diffractometer "Mastersizer", particle size analyzer "Laarmann"). Experimental studies were performed at least three times to obtain representative data and reduce error. The sample material size for all experiments was in the $-15+0 \mathrm{~mm}$ range. In order to investigate the possibility of selective disintegration 
of raw materials, experimental research was carried out on three types of crushers: jaw crusher, roll crusher, and impact crusher. The same closed-side setting was selected for all types of crushers, and all samples were crushed to the same $P_{80}$-value in order to make an accurate assessment. A single-toggle jaw crusher was used. An impact crusher with a speed of $3000 \mathrm{rpm}$ and a diameter of $300 \mathrm{~mm}$ was selected. All pieces of ore fed into the process were of equal size and equal weight so that all investigated parameters were identical and possible for comparison. The weight of the sample for crushing was $100 \mathrm{~g}$. The mass of the initial samples and their number remained constant for all types of crushers. Data on the particle size distribution of the samples after crushing were obtained by sieving the crushing products on sieves with hole sizes of $3200 \mu \mathrm{m}, 1600 \mu \mathrm{m}, 800 \mu \mathrm{m}, 400 \mu \mathrm{m}, 200 \mu \mathrm{m}$, and $100 \mu \mathrm{m}$. The obtained classes were weighed, after which representative samples were selected for analysis of the elemental composition. The computer program "STATISTICA" (STATISTICA 10.0, StatSoft, Tulsa, OK, USA) was used to process the experimental data.

\section{Results}

As a result of the petrographic characteristics investigation for the BDO, it was found that quartz, feldspars, and calcite prevail among the rock-forming minerals. Ore minerals have distinct intergrowth boundaries with rock-forming minerals (Figure 4 and Table 4).

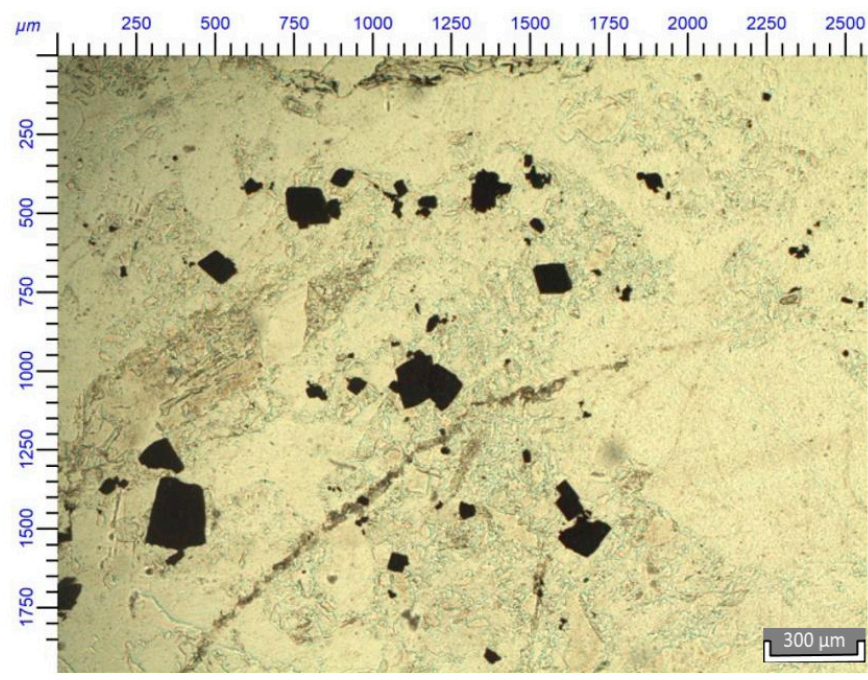

(a)

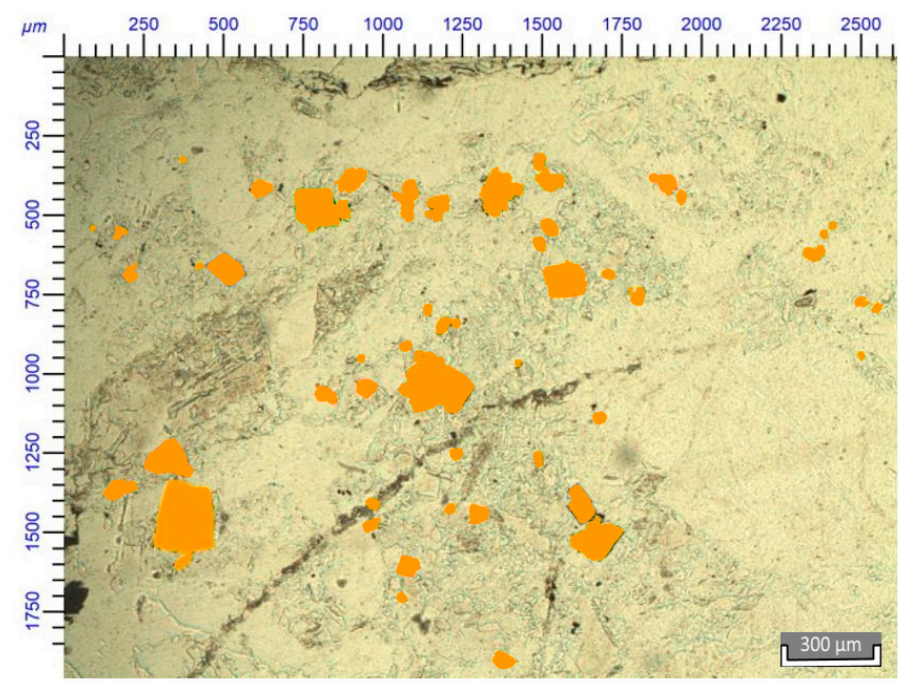

(b)

Figure 4. Measurement areas of ore mineralization BDO: (a) general view; (b) after treatment (ore mineralisation is highlighted in orange color).

Table 4. The results of linear measurements for ore mineralization CNO and BDO.

\begin{tabular}{cccc}
\hline \multirow{2}{*}{ o } & Parameter & \multicolumn{2}{c}{ Value } \\
\cline { 3 - 4 } & & CNO & BDO \\
\hline 1. & Area, $\mu \mathrm{m}^{2}$ & $357.357 \pm 17.868$ & $16.197 \pm 0.810$ \\
2. & Perimeter, $\mu \mathrm{m}$ & $2935 \pm 147$ & $531 \pm 27$ \\
3. & Form Factor F1 & $0.47 \pm 0.02$ & $0.6 \pm 0.03$ \\
4. & Form Factor F2 & $0.61 \pm 0.03$ & $0.59 \pm 0.03$ \\
5. & Continuity & $0.75 \pm 0.04$ & $0.81 \pm 0.04$ \\
6. & Oblongness, $L \backslash B$ & $4.76 \pm 0.24$ & $2.96 \pm 0.15$ \\
7. & Edge roughness & $1.22 \pm 0.06$ & $1.1 \pm 0.06$ \\
8. & Average distance between grains, $\mu \mathrm{m}$ & $1165 \pm 58$ & $300 \pm 15$ \\
\hline
\end{tabular}

The sample of $\mathrm{CNO}$ analysis suggests the idioblastic nature of the intergrowth of ore minerals with plagioclase. 
Figure 5 and Table 4 show the graphical results of the research before and after the separation of the investigated mineral grains and the results of linear measurements. Color highlights are made using the Thixomet software (Thixomet PRO, Thixomet, St. Petersburg, Russia) to identify areas in the figure where ore mineralization is represented. Based on the color highlights, the parameters shown in Table 4 are determined for each sample.

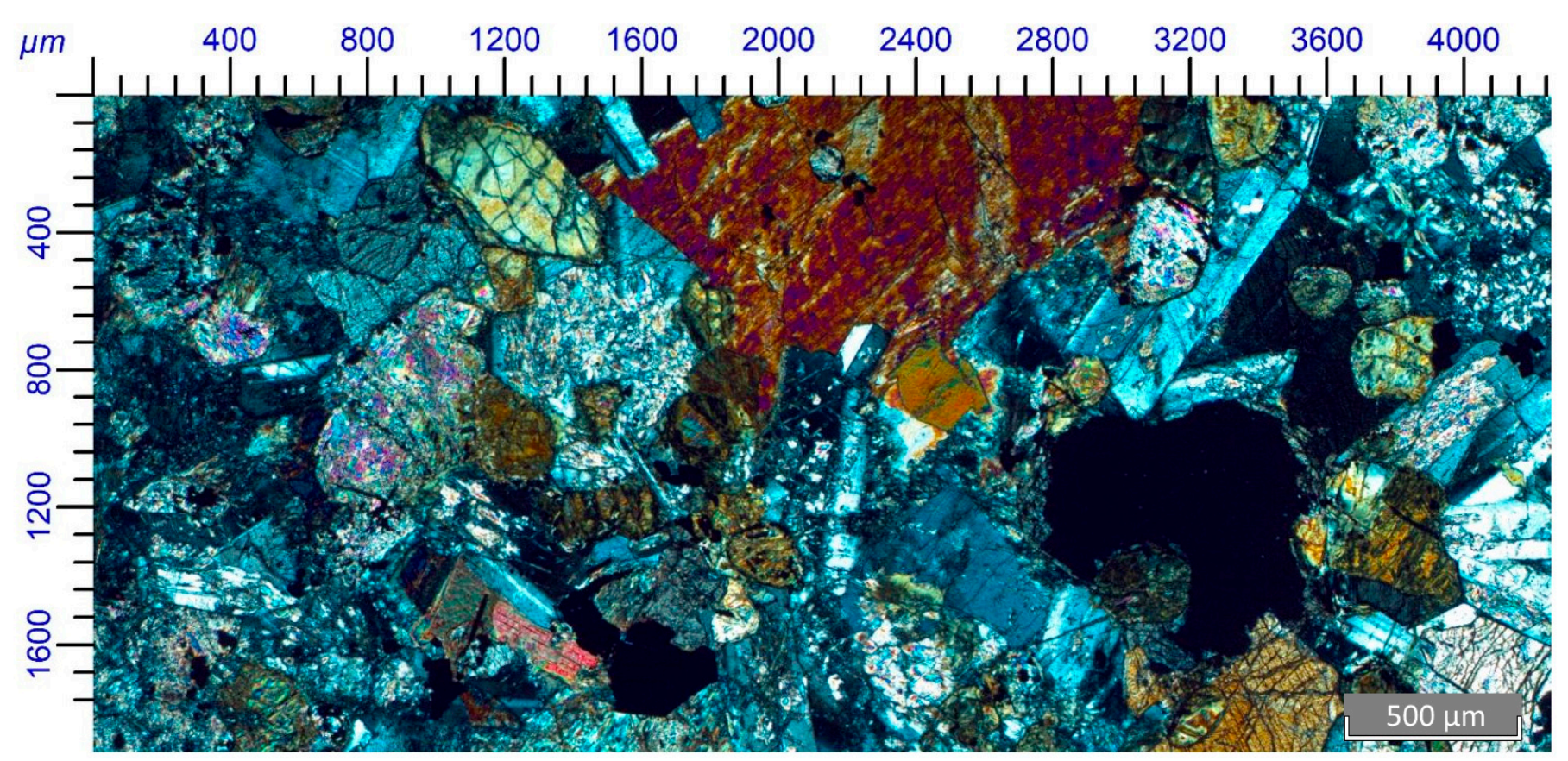

(a)

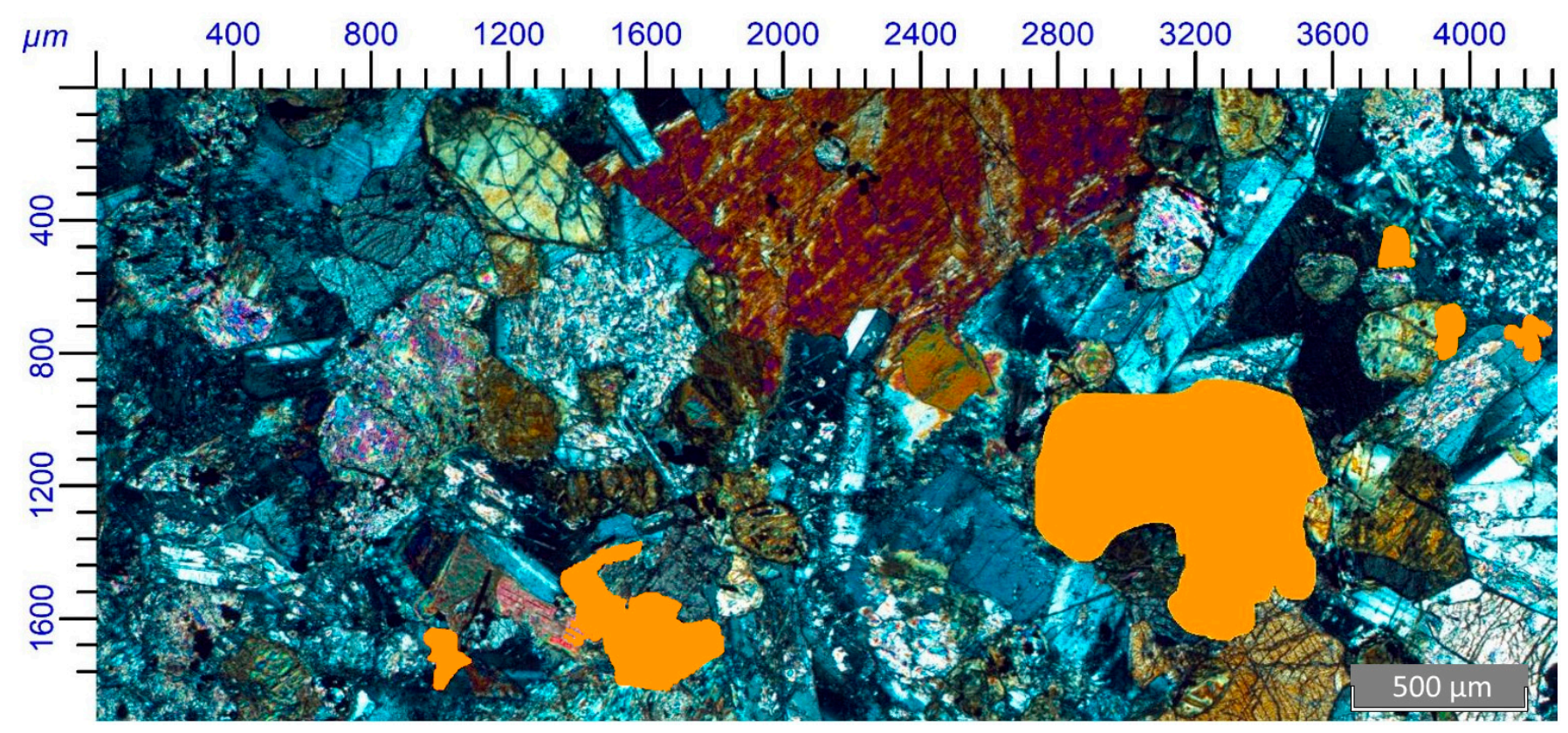

(b)

Figure 5. Measurement areas of ore mineralization CNO: (a) general view; (b) after treatment (ore mineralisation is highlighted in orange color). 
Because the samples are polymetallic (there are inclusions of minerals that differ significantly in energy consumption during fracture and in fracture rate), it is necessary to consider polymineralism as one of the priority signs at disintegration.

Using the CTvox and CTan programs (CTvox version 1.5.2 and CTan version 1.18, Brucker, Kontich, Belgium) it is possible to examine and analyze in detail not only the rock grain sizes, but also their interrelations. In addition, the X-ray microtomography method allows a number of morphometric parameters reflecting the structural-textural features of rocks and ores to be quickly and accurately characterized. The results of macro- and microscopic examination of the samples are shown in Figure 6.
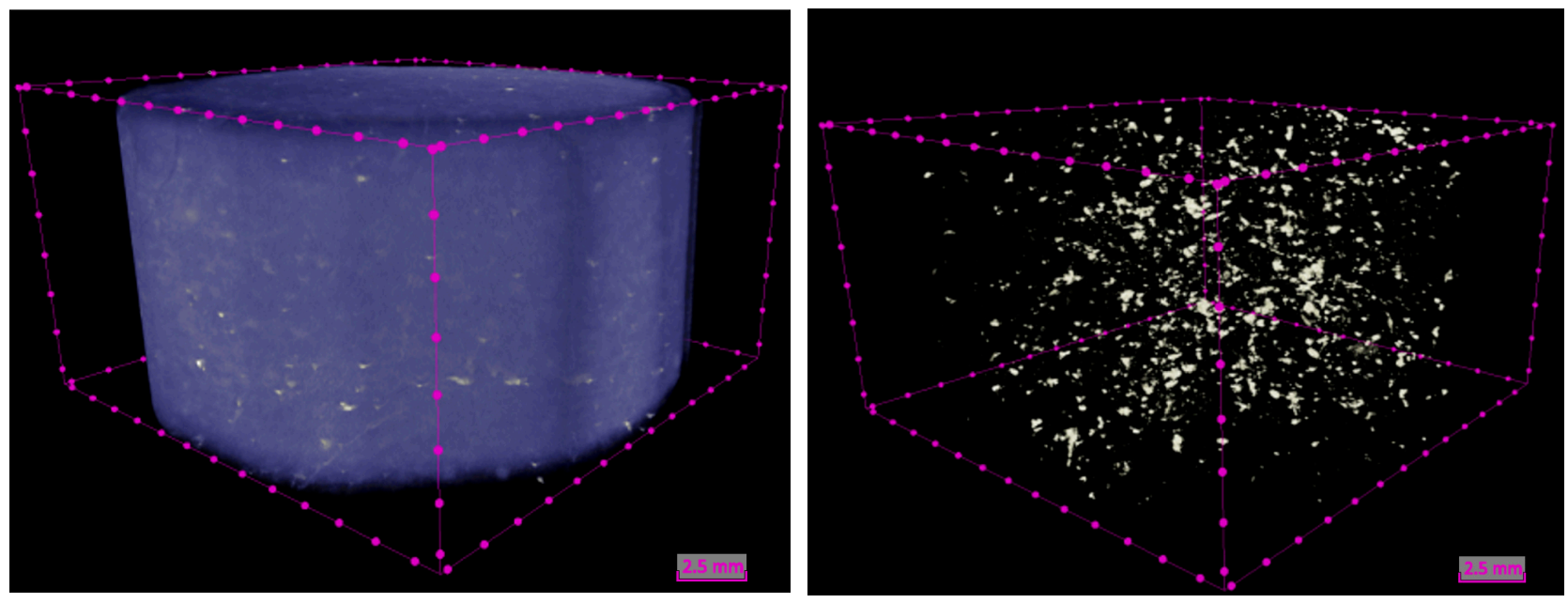

(a)
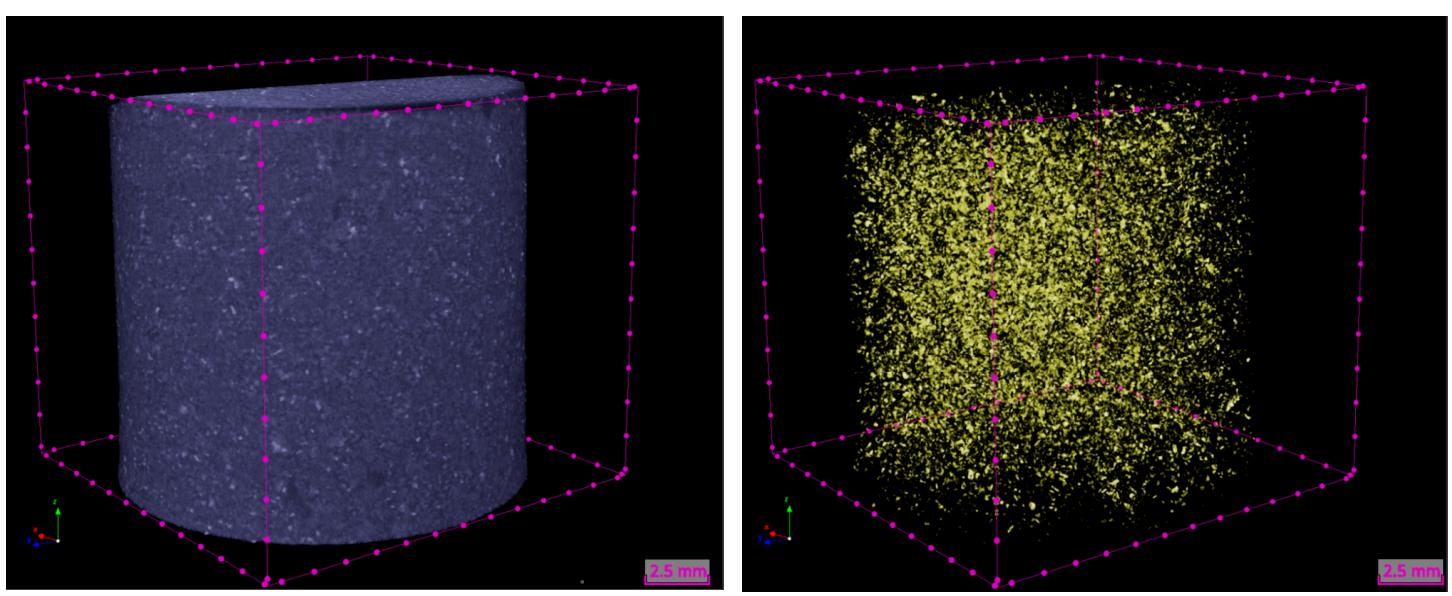

(b)

Figure 6. 3D visualization of the sample (left) and distribution of ore minerals in the rock volume (right): (a) BDO; (b) CNO.

The results of the research of these parameters are presented in Table 5.

Table 5. Analysis of morphometric indicators of the sample obtained by X-ray microtomography method.

\begin{tabular}{|c|c|c|c|c|c|c|c|}
\hline Ore Sample & $\begin{array}{c}\text { Isolated } \\
\text { Porosity } \\
\text { Volume, } \\
\mathrm{mm}^{3}\end{array}$ & $\begin{array}{c}\text { Isolated } \\
\text { Porosity } \\
\text { Area, mm² }\end{array}$ & $\begin{array}{c}\text { Isolated } \\
\text { Porosity, \% }\end{array}$ & $\begin{array}{c}\text { Effective } \\
\text { Porosity } \\
\text { Volume, } \\
\text { mm }^{3}\end{array}$ & $\begin{array}{c}\text { Effective } \\
\text { Porosity, \% }\end{array}$ & $\begin{array}{c}\text { Total } \\
\text { Porosity, \% }\end{array}$ & $\begin{array}{c}\text { Sphericity, } \\
\%\end{array}$ \\
\hline BDO & 1.58377 & 88.12997 & 0.27502 & 0.48812 & 0.08469 & 0.35948 & 0.72353 \\
\hline $\mathrm{CNO}$ & 4.90869 & 91.32154 & 0.61283 & 2.31945 & 0.28874 & 0.89980 & 0.82912 \\
\hline
\end{tabular}


The porosity factor often determines the rock strength characteristics and its behavior during disintegration since the destruction occurs along the weakest zones-the boundaries of individual mineral phases intergrowths, fractures [40-42]. When analyzing the pore space characteristics of the samples, it was revealed that the samples have a sufficiently low porosity, which indicates the high strength of the rock itself.

The investigation of physical and mechanical properties using modern methods [43-47] was also carried out. The results are shown in Table 6.

Table 6. Summary table of physical and mechanical properties of the investigated ore samples.

\begin{tabular}{|c|c|c|}
\hline Ore Sample & BDO & CNO \\
\hline \multicolumn{3}{|c|}{ JK Drop Weight test results } \\
\hline Parameter $A$ & $70.80 \pm 3.54$ & $99.90 \pm 4.95$ \\
\hline Parameter b & $0.53 \pm 0.021$ & $0.30 \pm 0.0015$ \\
\hline Multiplication $A \times b$ & $37.5 \pm 0.39$ & $30.00 \pm 0.64$ \\
\hline Abrasive parameter $t a$ & $0.49 \pm 0.05$ & $0.30 \pm 0.06$ \\
\hline Parameter SCSE * $(\mathrm{kWh} / \mathrm{t})$ & $11.07 \pm 0.34$ & $11.90 \pm 0.21$ \\
\hline \multicolumn{3}{|c|}{ F. Bonds' indexes determination } \\
\hline Ball mill work index BWI, kWh/t & $17.56 \pm 0.87$ & $11.96 \pm 0.54$ \\
\hline Crushing work index CWI, $\mathrm{kWh} / \mathrm{t}$ & $5.31 \pm 0.266$ & $21.82 \pm 1.09$ \\
\hline \multicolumn{3}{|c|}{ Allis Chalmers' abrasive tests } \\
\hline Abrasiveness index $A I, \mathrm{~g}$ & $0.2638 \pm 0.013$ & $0.1653 \pm 0.008$ \\
\hline \multicolumn{3}{|c|}{ Density determination } \\
\hline Bulk density (with tamping), $\mathrm{t} / \mathrm{m}^{3}$ & $2.08 \pm 0.07$ & $2.01 \pm 0.09$ \\
\hline
\end{tabular}

*SAG (Semi-Autogenous Mill) Circuit Specific Energy.

Thus, the BDO sample is hard in terms of ball grinding resistance and very soft in terms of crushability, consistent with the application range of jaw and cone industrial crushers, which characterizes the typical tendency of heterogeneous ore materials to increase their crushability as particle size decreases. The CNO sample is soft in terms of fracture resistance to impact crushing and moderately abrasive. According to the JK Drop Weight test results, both the low-energy fracture parameter and the complex high-energy fracture parameter $A \times b$, the $\mathrm{CNO}$ is of the hard ore type.

Therefore, to identify the possibility of selective disintegration and pre-concentration at the crushing stage, the samples were subjected to crushing in three types of devices: jaw, roll, and impact crushers. After crushing the samples of CNO and BDO for all types of crushers, the particle size was $P_{80}=2.6+0.5 \mathrm{~mm}$.

The material after crushing was subjected to sieve analysis, and each class was analyzed by XRF to establish patterns of distribution of components from the size class and type of crusher used (Figures 7-9 and Tables 7-9).

The products for BDO samples of all crushers are characterized by a predominance of $-4+1.6 \mathrm{~mm}$ sieve class. Since the silica minerals are the main rock-forming minerals, it was decided to look at the distribution of $\mathrm{Si}$ by sieve classes. According to analyses of the silica-bearing minerals distributions, it was found that the recovery of the silica-bearing minerals was maximum for the $-4+1.6 \mathrm{~mm}$ sieve class. However, the products of the impact crusher are characterized by the highest recovery of silicon-containing minerals in this class (up to $81.85 \%$ ). Such results suggest that the impact crusher at the crushing stage allows selective disintegration of this type of mineral assemblages along the intergrowth boundaries.

Analysis of the data (Table 7, Figure 7) for gold in crushing products shows that all types of crushers have the highest values for gold in the sieve class of $-1.6+0.8 \mathrm{~mm}$. This allows, for example, the use of gravity methods for gold recovery. The highest gold content and distribution in the $-1.6+0.8 \mathrm{~mm}$ sieve class was obtained for the impact crusher, which is possibly due to the unloading of the crushed products during crushing, thus avoiding over-crushing. 


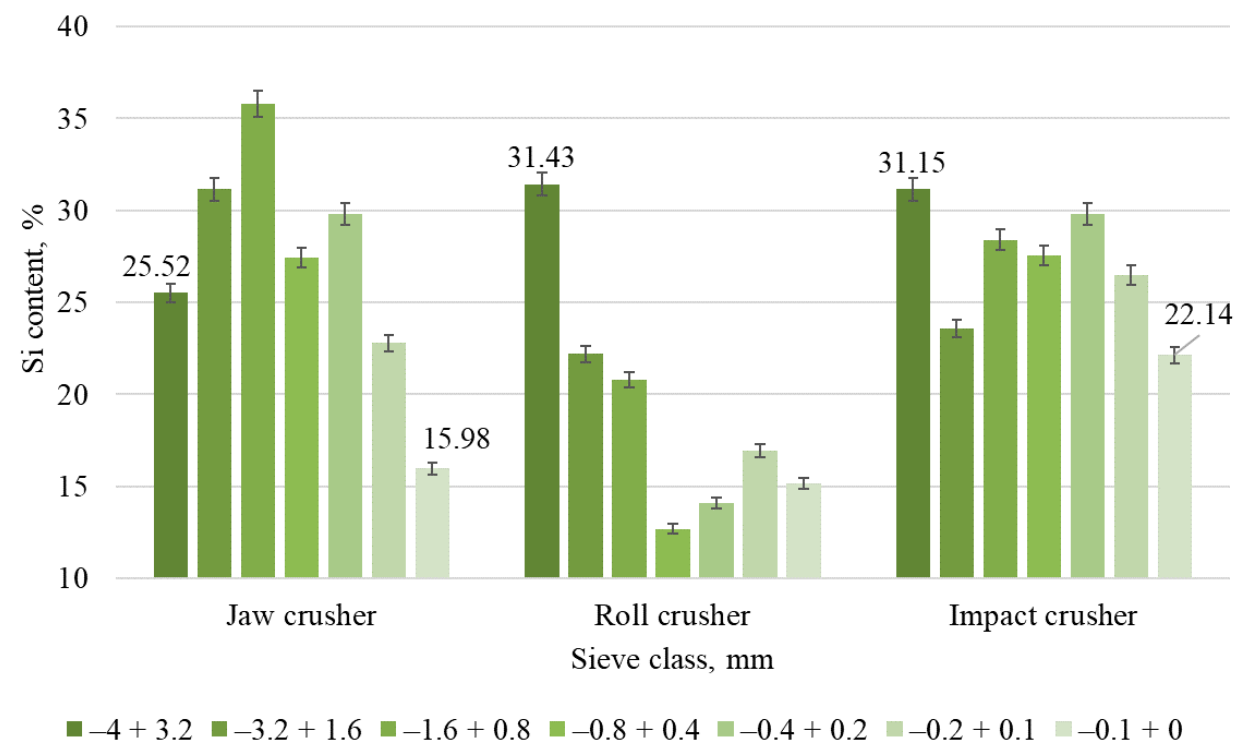

(a)

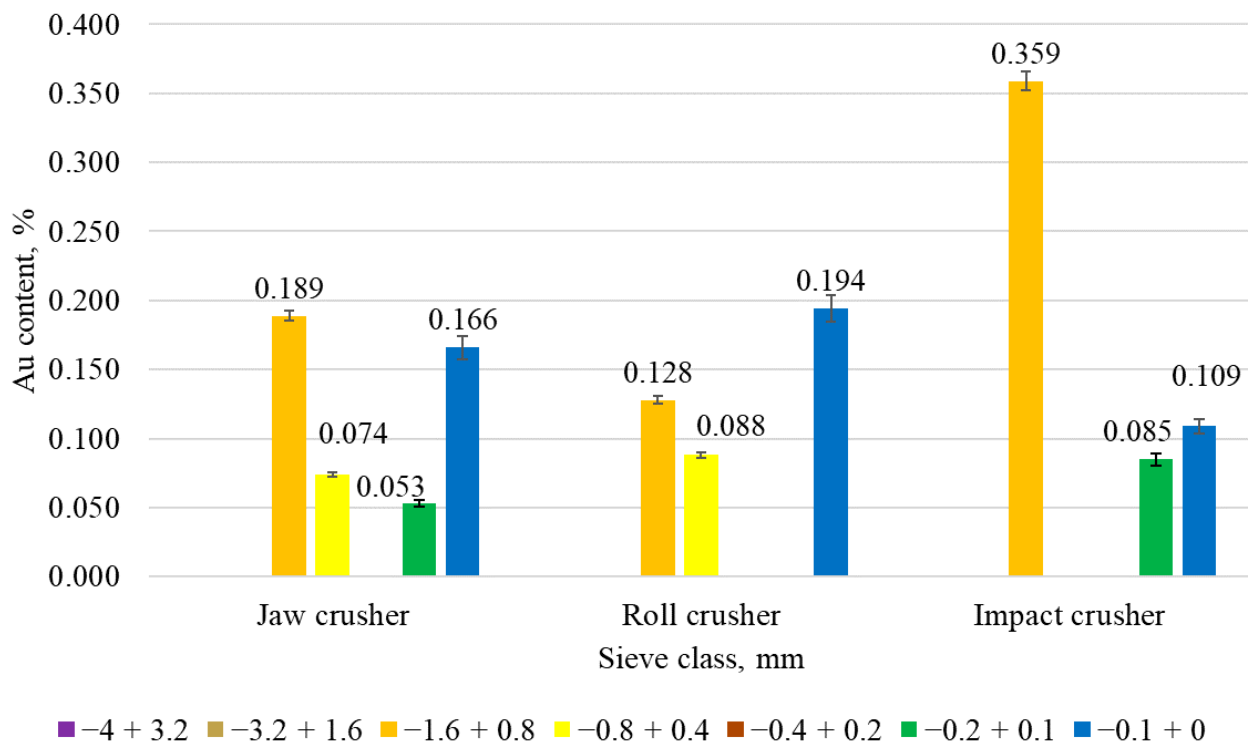

(b)

Figure 7. Silica (a) and gold (b) content in the sieve classes of BDO sample after crushing in jaw, roll and impact crushers. Emerging "T" signs from bars show that the measurment was provided three times and such standard deviations from the values are obtained.

Tables 8 and 9 show the distribution of the main elements of the rock-forming and ore minerals in the $\mathrm{CNO}$ crushing process. The concentrations of components by sieve classes are shown in Figures 8 and 9.

Analysis of the data in Figure 7 for the distribution of nickel in the sieve classes shows that nickel is mainly concentrated in the $-0.1+0 \mathrm{~mm}$ sieve class for all crusher types. Interpretation of the data obtained shows that for all types of crushers, an increase in nickel content is observed with a decrease in the sieve classes. It was found that the maximum nickel content in the sieve class of $-0.1+0 \mathrm{~mm}$ was obtained in the roll crusher at $2.346 \%$. The interpretation of the data on copper content in the sieve classes is similar, with the maximum copper content of $5.073 \%$ being obtained by crushing in a roller crusher. 


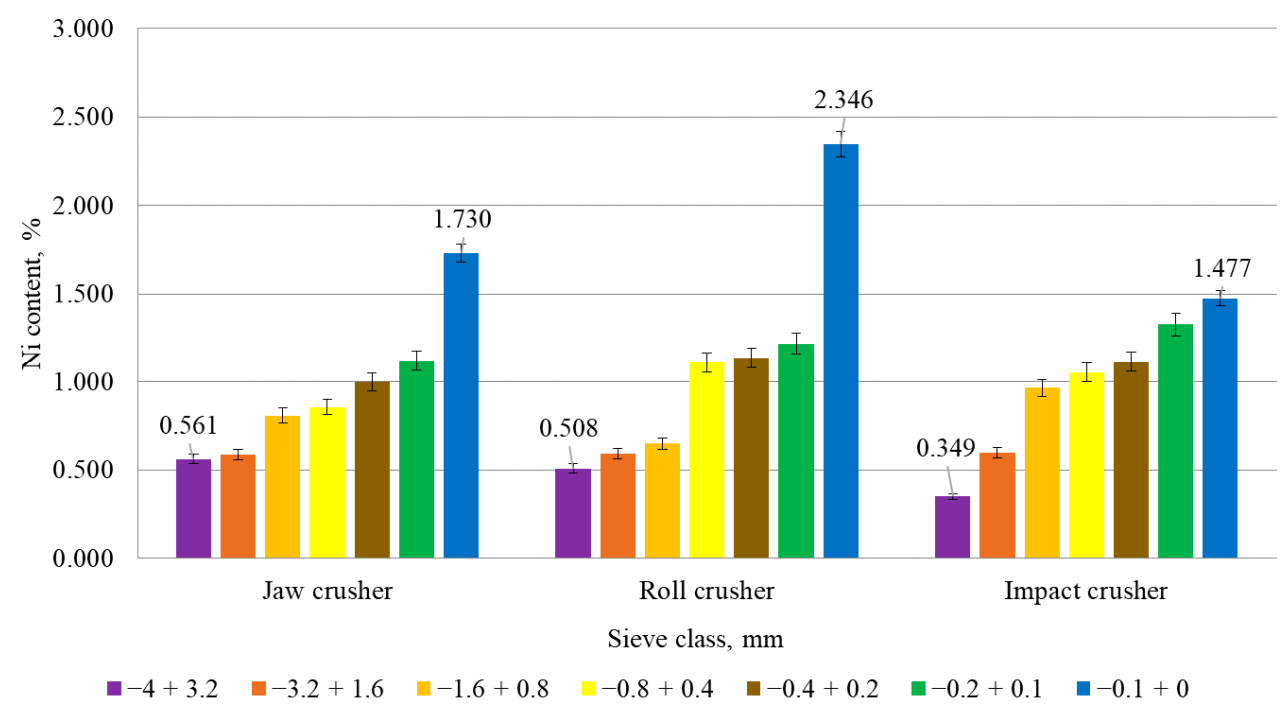

(a)

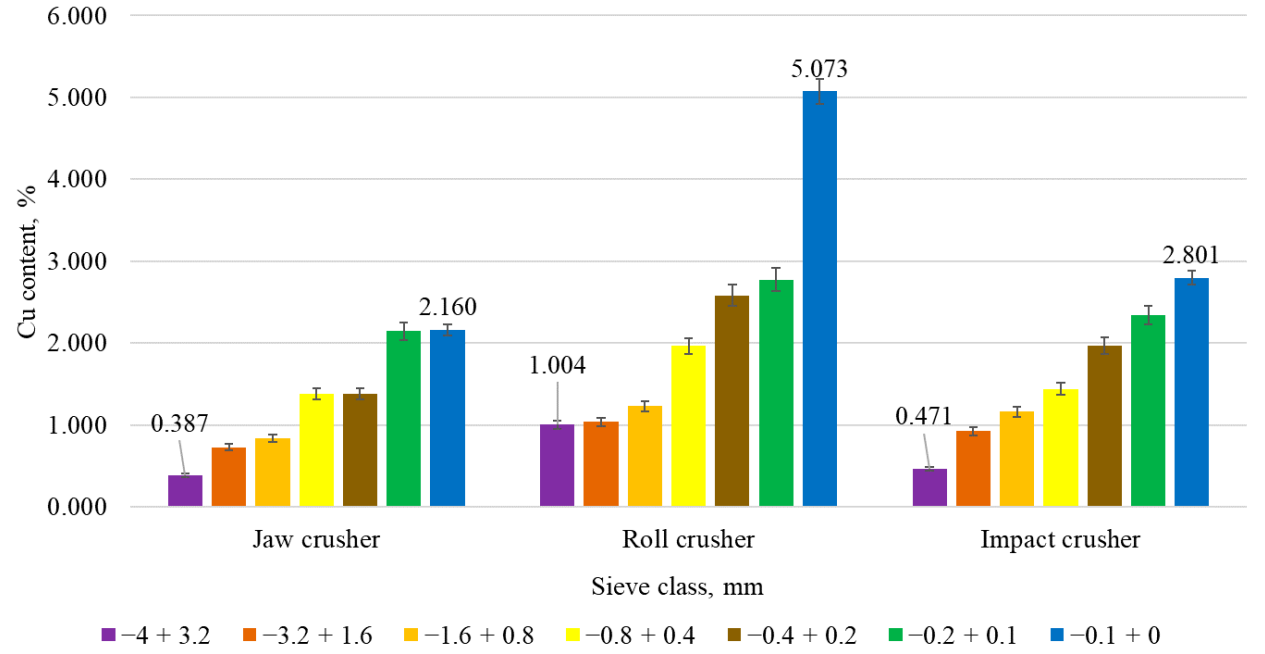

(b)

Figure 8. Nickel (a) and copper (b) content in the sieve classes of the crushing of CNO samples in jaw, roll and impact crushers.

Analysis of the distribution of the main elements of ore minerals by size classes, presented in Table 6, allows us to determine that crushing in the roll crusher results in $13.28 \%$ of copper and $11.98 \%$ of nickel of their total ore content being transferred to the $-0.1+0$ mm class. It should be noted that crushing in an impact crusher, as opposed to a jaw crusher, results in a more even distribution of components across the sieve classes, despite lower copper and nickel content.

The main rock-forming minerals in the copper-nickel ore samples are plagioclase, pyroxene, and olivine. The significant difference in densities between the ore minerals and the rock-forming minerals enables their selective disintegration and allocation to different size classes. Analysis of the data presented in Figure 8 shows that all crusher types are characterized by a decrease in silica and calcium content as the sieve class decreases. As with the previous data, the calcium and silica content in the sieve class of $-0.1+0 \mathrm{~mm}$ crusher has minimum values of $12.00 \%$ and $4.69 \%$, respectively, when crushed in the roller crusher. 


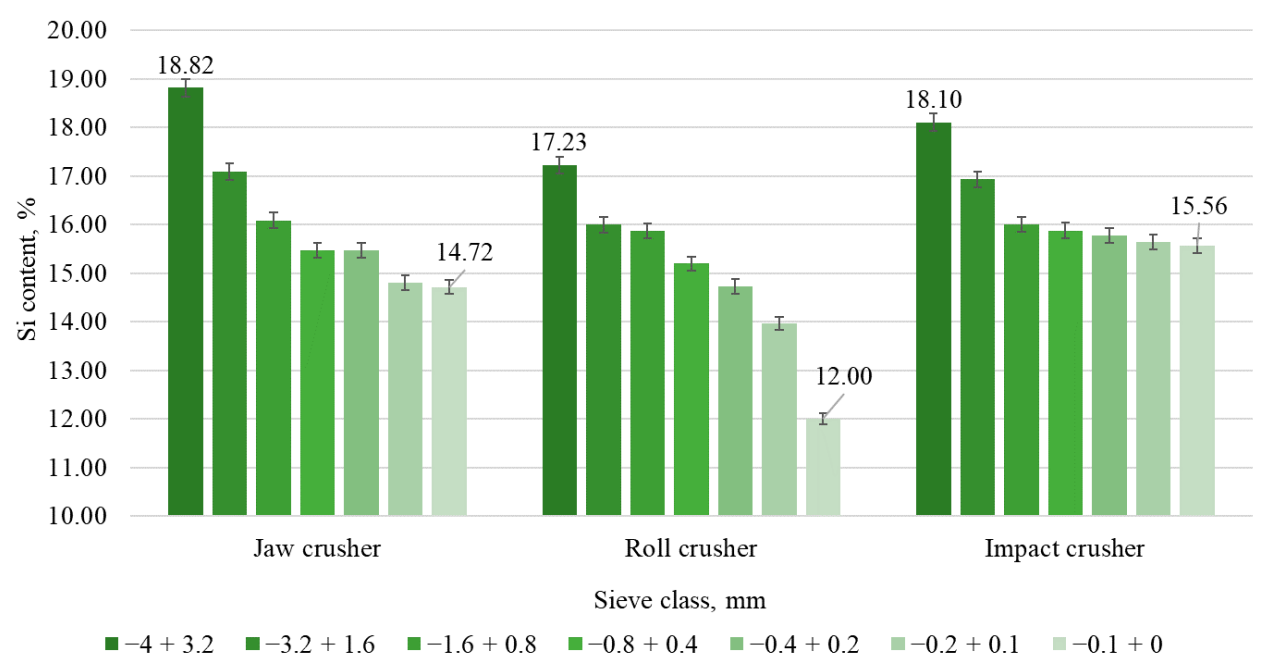

(a)

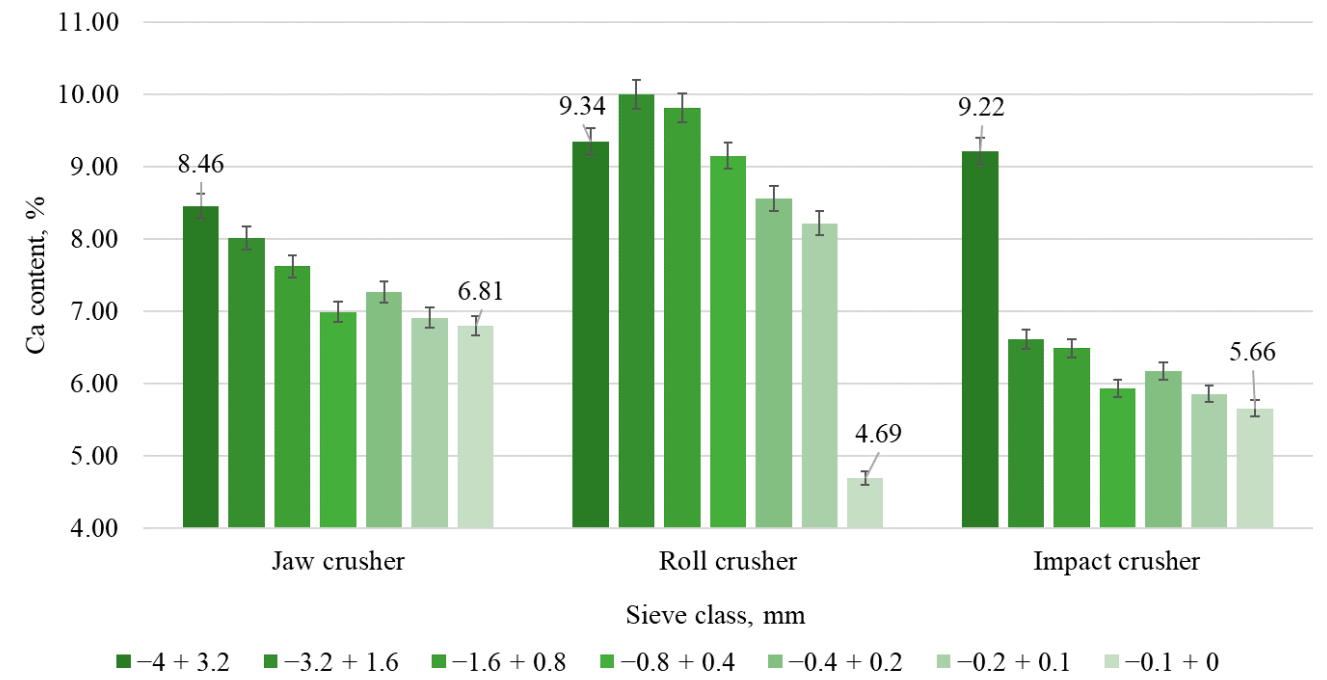

(b)

Figure 9. Silica (a) and calcium (b) content in the sieve classes during the crushing of the CNO samples in jaw, roll and impact crushers.

Table 7. Distribution of silica and gold in the sieve classes for BDO crushing products.

\begin{tabular}{ccccccc}
\hline \multirow{2}{*}{$\begin{array}{c}\text { Sieve Class. } \\
\text { mm }\end{array}$} & \multicolumn{3}{c}{ Si Distribution. \% } & \multicolumn{3}{c}{ Au Distribution. \% } \\
\cline { 2 - 7 } & $\begin{array}{c}\text { Roll } \\
\text { Crusher }\end{array}$ & $\begin{array}{c}\text { Impact } \\
\text { Crusher }\end{array}$ & $\begin{array}{c}\text { Jaw } \\
\text { Crusher }\end{array}$ & $\begin{array}{c}\text { Roll } \\
\text { Crusher }\end{array}$ & $\begin{array}{c}\text { Impact } \\
\text { Crusher }\end{array}$ & $\begin{array}{c}\text { Jaw } \\
\text { Crusher }\end{array}$ \\
\hline$-4+3.2$ & 52.881 & 76.171 & 65.702 & 0.000 & 0.000 & 0.000 \\
$-3.2+1.6$ & 28.749 & 8.544 & 16.660 & 0.000 & 0.000 & 0.000 \\
$-1.6+0.8$ & 7.833 & 5.530 & 7.583 & 63.148 & 80.191 & 68.005 \\
$-0.8+0.4$ & 3.371 & 2.516 & 3.595 & 16.839 & 0.000 & 11.622 \\
$-0.4+0.2$ & 3.646 & 2.722 & 3.123 & 0.000 & 0.000 & 0.000 \\
$-0.2+0.1$ & 3.341 & 2.883 & 2.359 & 0.000 & 10.591 & 7.144 \\
$-0.1+0$ & 0.179 & 1.635 & 0.978 & 20.013 & 9.218 & 13.230 \\
\hline
\end{tabular}

The distribution of the rock-forming minerals' main components into the fine size classes are presented in Table 7. It shows that the percentage of distribution of calcium into the $-0.1+0 \mathrm{~mm}$ class has a minimum value for the roller crusher, while for silica, the minimum value is observed for crushing in the jaw crusher. 
Interpretation of the obtained data allows the selective disintegration possibility to be justified for $\mathrm{CNO}$, both from the perspective of mineralogical and technical features and from the perspective of experimental studies using different types of crushing units.

Table 8. Copper and nickel distribution in sieve classes for CNO for different types of crushers.

\begin{tabular}{ccccccc}
\hline \multirow{2}{*}{$\begin{array}{c}\text { Sieve Class, } \\
\text { mm }\end{array}$} & \multicolumn{3}{c}{ Cu Distribution, \% } & \multicolumn{3}{c}{ Ni Distribution, \% } \\
\cline { 2 - 7 } & $\begin{array}{c}\text { Jaw } \\
\text { Crusher }\end{array}$ & $\begin{array}{c}\text { Roll } \\
\text { Crusher }\end{array}$ & $\begin{array}{c}\text { Impact } \\
\text { Crusher }\end{array}$ & $\begin{array}{c}\text { Jaw } \\
\text { Crusher }\end{array}$ & $\begin{array}{c}\text { Roll } \\
\text { Crusher }\end{array}$ & $\begin{array}{c}\text { Impact } \\
\text { Crusher }\end{array}$ \\
\hline$-4+3.2$ & 43.42 & 25.28 & 31.64 & 59.47 & 24.91 & 34.49 \\
$-3.2+1.6$ & 14.69 & 24.98 & 14.05 & 11.06 & 27.70 & 13.34 \\
$-1.6+0.8$ & 10.57 & 11.75 & 13.11 & 9.62 & 12.06 & 16.02 \\
$-0.8+0.4$ & 8.77 & 9.11 & 9.63 & 5.13 & 10.01 & 10.35 \\
$-0.4+0.2$ & 6.50 & 8.50 & 11.55 & 4.43 & 7.28 & 9.62 \\
$-0.2+0.1$ & 7.06 & 7.08 & 11.32 & 3.49 & 6.06 & 9.43 \\
$-0.1+0$ & 8.99 & 13.28 & 8.70 & 6.80 & 11.98 & 6.75 \\
\hline
\end{tabular}

Table 9. Silica and calcium distribution in sieve classes for CNO for different types of crushers.

\begin{tabular}{ccccccc}
\hline \multirow{2}{*}{$\begin{array}{c}\text { Sieve Class, } \\
\text { mm }\end{array}$} & \multicolumn{3}{c}{ Si Distribution, \% } & \multicolumn{3}{c}{ Ca Distribution, \% } \\
\cline { 2 - 7 } & $\begin{array}{c}\text { Jaw } \\
\text { Crusher }\end{array}$ & $\begin{array}{c}\text { Roll } \\
\text { Crusher }\end{array}$ & $\begin{array}{c}\text { Impact } \\
\text { Crusher }\end{array}$ & $\begin{array}{c}\text { Jaw } \\
\text { Crusher }\end{array}$ & $\begin{array}{c}\text { Roll } \\
\text { Crusher }\end{array}$ & $\begin{array}{c}\text { Impact } \\
\text { Crusher }\end{array}$ \\
\hline$-4+3.2$ & 71.86 & 37.53 & 61.54 & 71.06 & 34.94 & 67.70 \\
$-3.2+1.6$ & 11.66 & 33.29 & 13.01 & 12.03 & 35.71 & 10.98 \\
$-1.6+0.8$ & 6.90 & 13.10 & 9.13 & 7.20 & 13.91 & 8.00 \\
$-0.8+0.4$ & 3.35 & 6.09 & 5.36 & 3.33 & 6.30 & 4.34 \\
$-0.4+0.2$ & 2.48 & 4.19 & 4.68 & 2.56 & 4.19 & 3.96 \\
$-0.2+0.1$ & 1.66 & 3.08 & 3.83 & 1.70 & 3.12 & 3.10 \\
$-0.1+0$ & 2.09 & 2.72 & 2.45 & 2.12 & 1.83 & 1.92 \\
\hline
\end{tabular}

\section{Conclusions}

The results of experimental mineralogical and technological properties investigation for the selected objects made it possible to establish interrelationships between mineralogical, microstructural, and technological characteristics. Both quantitative and qualitative assessment of strength properties of the investigated materials was made on the basis of the obtained values, the results of which allow their fracture rates in industrial crushing and grinding equipment to be predicted.

Structural and textural features were researched by means of $X$-ray computed microtomography. Analysis of pore space characteristics of the samples revealed that the sample has low porosity $(0.36 \%-\mathrm{BDO}$ and $0.90 \%-\mathrm{CNO})$, which indicates the high strength of the rock itself. Additionally, the investigation on the crushing of the BDO and the CNO samples in different types of crushers was provided. For BDO, it was found that rock-forming minerals are concentrated in coarse sieve classes, especially for impact crushers (up to $81.85 \%$ of silica-containing minerals in sieve class of $-4+2 \mathrm{~mm}$ ). For the CNO crushing in all three types of crushers, an increase in the content of major ore mineral elements such as copper and nickel in the fine sieve classes was observed, with the simultaneous increase in the content of silica and calcium in the coarse sieve classes. These investigations will justify the possibility of selective disintegration for copper-nickel ores.

The received results verify the wide range of possibilities of the application of the considered set of methods. For example, for disintegration mechanisms investigation, liberation models creation, contents of ore minerals estimation for mineral assemblages, analysis of grain size distribution, etc. Moreover, it allows for the evaluation of the possibility of selective disintegration implementation for investigated objects, which can influence the increase in efficiency of recovery of valuable components at the following stages of mineral processing. 
Author Contributions: T.A.-conceived, designed the experiments, and analyzed the data; N.N.implementation and processing of the analysis results; A.A., A.R. and V.K.-performed the experiments. All authors have read and agreed to the published version of the manuscript.

Funding: This work was financially supported by the Russian Foundation for Fundamental Research (Project No. 20-55-12002).

Data Availability Statement: Not applicable.

Conflicts of Interest: The authors declare no conflict of interest.

\section{References}

1. Litvinenko, V.S. Russian state policy in the field of mineral resources and legislative support for mining relations. J. Min. Inst. 2005, 166, 8-10.

2. Litvinenko, V.S. Digital economy as a factor in the technological development of the mineral sector. Nat. Resour. Res. 2020, 29, 1521-1541. [CrossRef]

3. Chanturiya, V.A.; Vaysberg, L.A.; Kozlov, A.P. Promising trends in investigations aimed at all round utilization of mineral raw materials. Obogashchenie Rud 2014, 2, 3-9. [CrossRef]

4. Nevskaya, M.; Cherepovitsyn, A. Justification of an approach to an economic assessment of projects development of technogenic mineral objects. IOP Conf. Ser. Earth Environ. Sci. 2019, 302, 1-6. [CrossRef]

5. Kruk, M.N.; Guryleva, N.S.; Cherepovitsyn, A.E.; Nikulina, A.Y. Opportunities for improving the corporate social responsibility programs for metallurgical companies in the arctic. Non-Ferr. Met. 2018, 44, 3-6. [CrossRef]

6. Vaisberg, L.A.; Kononov, O.V.; Ustinov, I.D. Fundamentals of Geometallurgy; Russian Collection: St. Petersburg, Russia, $2020 ;$ p. 376.

7. Alexandrova, T.N.; O'Connor, C. Processing of platinum group metals ores in Russia and South Africa: Current state and prospects. Journal of Mining Institute. 2020, 244, 462-473. [CrossRef]

8. Romashev, A.O. Use of additive technologies to optimize design of classifying devices. IOP Conf. Ser. Mater. Sci. Eng. 2019, 665, 012009. Available online: https:/ /iopscience.iop.org/article/10.1088/1757-899X/665/1/012009/pdf (accessed on 10 June 2021). [CrossRef]

9. Mariano, R.A.; Evans, C.L.; Manlapig, E. Definition of random and non-random breakage in mineral liberation-A review. Miner. Eng. 2016, 94, 51-60. [CrossRef]

10. Vizcarra, T.G.; Wightman, E.M.; Johnson, N.W.; Manlapig, E.V. The effect of breakage mechanism on the mineral liberation properties of sulphide ores. Miner. Eng. 2010, 23, 374-382. [CrossRef]

11. Lois-Morales, P.; Evans, C.; Weatherley, D. Characterising tensile strength and elastic moduli of altered igneous rocks at comminution scale using the short impact load cell. Powder Technol. 2021, 388, 343-356. [CrossRef]

12. Wang, Y. Numerical modelling of heterogeneous rock breakage behaviour based on texture images. Miner. Eng. 2015, 74, 130-141. [CrossRef]

13. Hopunov, E.A. Selective Destruction of Mineral and Anthropogenic Raw Materials. In Beneficiation and Metallurgy; UIPC LLC: Ekaterinburg, Russia, 2013; p. 429.

14. Morrell, S. A method for predicting the specific energy requirement of comminution circuits and assessing their energy utilisation efficiency. Miner. Eng. 2008, 21, 3. [CrossRef]

15. Hesse, M.; Popov, O.; Lieberwirth, H. Increasing efficiency by selective comminution. Miner. Eng. 2017, 103-104, 112-126. [CrossRef]

16. Lieberwirth, H.; Kühnel, L. Particle size effects on selectivity in confined bed comminution. Minerals 2021, 11, 342. [CrossRef]

17. Lvov, V.; Sishchuk, J.; Chitalov, L. Intensification of bond ball mill work index test through various methods. In Proceedings of the International Multidisciplinary Scientific GeoConference Surveying Geology and Mining Ecology Management, SGEM, Albena, Bulgaria, 29 June-5 July 2017; Volume 17, pp. 857-864.

18. Hopunov, E.A. The role of structure and strength characteristics of minerals in ore fracture and opening. Obogashchenie Rud 2011, $1,25-31$.

19. Khopunov, E.A. The role of loading factors in formation of selective destruction of ores. Obogashchenie Rud 2011, 2, 24-30.

20. Ramdor, P. Ore Minerals and Their Intergrowths; Mir: Moscow, Russia, 1962; 1132p.

21. Vorontsova, N.I.; Duryagina, A.M.; Talovina, I.V. Ore field structures of the Uralian supergene Nickel deposits/Innovation-Based Development of the Mineral Resources Sector: Challenges and Prospects. In Proceedings of the 11th Russian-German Raw Materials Conference, Potsdam, Germany, 7-8 November 2018; pp. 147-153, ISBN 978-036707726-6.

22. Petrov, G.V.; Boduen, A.J.; Mardari, I.I.; Ivanov, B.S.; Boginskaya, A.S. Resources of noble metals in technogenic objects of mining and metallurgical complex of Russia. Adv. Mod. Nat. Sci. 2013, 3, 145-148.

23. Petruk, W. Applied Mineralogy in the Mining Industry; Elsevier: Amsterdam, The Netherlands, 2000; 267p.

24. Greg, S.; Sing, K. Adsorption, Specific Surface, Porosity; Mir: Moscow, Russia, 1984; p. 310.

25. Sulimova, M.A.; Litvinova, T.E. Metallurgical production waste treatment efficiency increase. In Proceedings of the International Multidisciplinary Scientific GeoConference: SGEM, Albena, Bulgaria, 30 June-6 July 2016; Volume 2, pp. 569-575. 
26. Nikandrov, S.N. Harmonized system of classifications of the main groups of rock-forming minerals (amphiboles, pyroxenes, mica) as matrix models. In Geology and Mineralogy of the Ilmenogorsky Complex: Situation and Problems; Ilmen State Reserve Ural Branch RAS: Miass, Russia, 2006; pp. 131-160.

27. Izuitko, V.M. Technological Mineralogy and Ore Evaluation; Nauka: Saint Petersburg, Russia, 1997; 532p.

28. Tong, L.; Klein, B.; Zanin, M.; Quast, K.; Skinner, W.; Addai-Mensah, J.; Robinson, D. Stirred milling kinetics of siliceous goethitic nickel laterite for selective comminution. Miner. Eng. 2013, 49, 109-115. [CrossRef]

29. Mwang, A.; Parian, M.; Lamberg, P.; Rosenkranz, J. Comminution modeling using mineralogical properties of iron ores. Miner. Eng. 2017, 111, 182-197. [CrossRef]

30. Huang, W.; Shi, F. Improving high voltage pulse selective breakage for ore pre-concentration using a multiple-particle treatment method. Miner. Eng. 2018, 128, 195-201. [CrossRef]

31. Hesse, M. Selective comminution for dry pre-concentration and energy saving. Innovation-Based Development of the Mineral Resources Sector: Challenges and Prospects. In Proceedings of the 11th Russian-German Raw Materials Conference, Potsdam, Germany, 7-8 November 2018; CRC Press: Boca Raton, FL, USA, 2018; p. 167.

32. Tataurov, S.B. Improvement of geotechnologies of heap leaching of gold using cryogenic disintegration of ores. Notes Min. Inst. 2011, 190, 126.

33. Litvinenko VS, Sergeev IB Innovative development of the mineral resource sector. Probl. Forecast. 2019, 6, 177.

34. Litvinenko, V.S.; Vaisberg, L.A. Address of the Chairman of the Congress Leonid Weisberg and the Rector of the Mining University Vladimir Litvinenko. Coal 2016, 6, 6.

35. Pronin, E.M.; Vasiliev, V.E.; Yu, T.V. Factors that determine the sustainable development of enterprises of the mineral resource complex, and their impact on the assessment of the results of the activities of enterprises. Zap. Gorn. Inst. 2011, 191, 176.

36. Veasey, T.J.; Wills, B.A. Review of methods of improving mineral liberation. Miner. Eng. 1991, 4, 747-752. [CrossRef]

37. Stepanov, V.A.; Strikha, V.E.; Cheremisin, A.A.; Shmuraeva, L.Y.; Danilov, A.A.; Kotov, N.V.; Poritskaya, L.G.; Poritsky, M.S.; Sokolov, S.V. Bamskoe Gold Deposit. In Geology, Mineralogy, Geochemistry; Dalnauka: Vladivostok, Russia, $1998 ;$ p. 203.

38. Zolotukhina, L.V.; Nosova, O.V.; Narbekova, T.N. Behavior of noble metals when enriching Noril'sk ore. Sci. Bull. Norilsk. Ind. Inst. 2014, 14, 42-52.

39. OOO Tiksomet. Step-by-Step Guide Thixomet PRO_MET; OOO Tiksomet: Saint Petersburg, Russia, 2016 ; pp. 179-193.

40. Evans, C.L.; Wightman, E.M.; Yuan, X. Quantifying mineral grain size distributions for process modelling using X-ray microtomography. Miner. Eng. 2015, 82, 78-83. [CrossRef]

41. Willson, C.W.; Lu, N.; Likos, W.J. Quantification of grain, pore and fluid microstructure of unsaturated sand from X-Ray CT images. Geotech. Test. J. 2012, 35, 6. [CrossRef]

42. Popov, O.; Talovina, I.; Lieberwirth, H.; Duryagina, A. Quantitative microstructural analysis and x-ray computed tomography of ores and rocks-Comparison of results. Mineral 2020, 10, 129. [CrossRef]

43. Bond, F.C. Crushing and Grinding Calculations Parts I and II. Br. Chem. Eng. 1961, 6, 6-8.

44. Bond, F.C. Crushing Tests by Pressure and Impact. Trans. AIME 1947, 169, 58-66.

45. Levin, J. Observation on the bond standard grindability test, and a proposal for a standard grindability test for fine materials. SAIMM 1989, 89, 13-21.

46. Gupta, A.; Yan, D.S. Mineral Processing Design and Operations: An Introduction; Elsevier: Amsterdam, The Netherlands, 2008.

47. Mular, A.L.; Halbe, D.N.; Barratt, D.J. (Eds.) Mineral Processing Plant Design, Practice, and Control; Society for Mining, Metallurgy, and Exploration, Inc.: Englewood, CO, USA, 2002; Volume 1. 